\title{
Elevated Carbon Dioxide and Soil Moisture on Early Growth Response of Soybean
}

\author{
M. Madhu ${ }^{*}$, Jerry L. Hatfield ${ }^{2}$ \\ ${ }^{1}$ Indian Institute of Soil and Water Conservation (IISWC), Research Centre, Koraput, India \\ ${ }^{2}$ National Laboratory for Agriculture and the Environment (NLAE), Ames, USA \\ Email: * madhupmd@gmail.com, jerry.hatfield@ars.usda.gov
}

Received 3 February 2015; accepted 25 February 2015; published 27 February 2015

Copyright (C) 2015 by authors and Scientific Research Publishing Inc.

This work is licensed under the Creative Commons Attribution International License (CC BY). http://creativecommons.org/licenses/by/4.0/

cc) (i) Open Access

\begin{abstract}
Interactions between elevated $\left[\mathrm{CO}_{2}\right]$ and soil water availability have the potential impact on crops and future food security of the world. The study was conducted to investigate vegetative growth response of soybeans under two $\left[\mathrm{CO}_{2}\right]\left(380\right.$ and $\left.800 \mu \mathrm{mol} \mathrm{mol}^{-1}\right)$ with three soil moisture levels in controlled environment. Slow growth rate and altered crop phenology of soybeans were observed under elevated $\left[\mathrm{CO}_{2}\right]$ at early stage $(\mathrm{V}-3 / \mathrm{V}-4)$, but showed positive physiologically response at later stage (R3) indicating adoptive mechanism of plants to high $\left[\mathrm{CO}_{2}\right]$. Elevated $\left[\mathrm{CO}_{2}\right]$ decreases the number of leaves by $23 \%$ and $14 \%$ and reduces in leaf areas by $11.7 \%$ and $9.7 \%$ compared with ambient $\left[\mathrm{CO}_{2}\right]$ at 29 and 44 days after planting (DAP), respectively. Adaptive mechanism of plants to high $\left[\mathrm{CO}_{2}\right]$ produced $39 \%$ and $83.7 \%$ greater leaf number and leaf areas, respectively at later stage (R3) of the crop growth (59 DAP). There was a reduction in a specific leaf area (SLA) at 29 DAP (22.2\%) but an increase at 44 DAP $(1.4 \%)$ and 58 DAP $(8.5 \%)$ under elevated $\left[\mathrm{CO}_{2}\right]$. Dry matter production of plants was increased significantly for elevated $\left[\mathrm{CO}_{2}\right]$. Increase in leaf $\mathrm{C}(<1 \%)$ and reduction in $\mathrm{N}$ concentration $(6.0 \%-9.5 \%)$ increased the $\mathrm{C}: \mathrm{N}$ ratio of soybean leaves $(4.4 \%$ $12.98 \%)$ under elevated $\left[\mathrm{CO}_{2}\right]$. Elevated $\left[\mathrm{CO}_{2}\right]$ with normal soil moisture condition produced a maximum number of pods $(54.8 \%-122.4 \%)$ and an increase in dry weight of pods $(29.8 \%-56.6 \%)$. Plants under elevated $\left[\mathrm{CO}_{2}\right]$ produced significantly greater numbers of root nodules per plant by $114 \%$ compared with plants under ambient $\left[\mathrm{CO}_{2}\right]$ at $44 \mathrm{DAP}$. These results show a direct and interactive effect of elevated $\left[\mathrm{CO}_{2}\right]$ and soil moisture on plant growth that will affect not only the global food security but also nutritional security.
\end{abstract}

\section{Keywords}

Elevated Carbon Dioxide, Dry Matter, Interaction Effect, Growth Response, Phenology, Root Nodules, Soil Moisture

*Corresponding author. 


\section{Introduction}

Atmospheric concentrations of carbon dioxide have been steadily rising with an average annual increase rate of about 2 ppm [1] and continued to rise to 500 - 1000 ppm by the year 2100 [1] [2] from current atmospheric average of approximately $385 \mathrm{ppm}$ [3]. The direct impact of rising atmospheric $\left[\mathrm{CO}_{2}\right]$ concentration on plants includes increase in photosynthetic rate [4]-[6], growth [7]-[9], reduction in nutrient concentration of plants [10] [11], reduction in leaf nitrogen concentration [12]-[14], increased C:N ratio [15] [16] and increased flowering and fruiting [15]-[21], and yield of agricultural crops [2] [22] [23], and is also expected to increase water use efficiency of crops [2] [4]. Productivity of most agricultural crops increases under elevated $\left[\mathrm{CO}_{2}\right]$ is in the range of $15 \%$ to $41 \%$ for $\mathrm{C} 3$ crops and $5 \%$ to $10 \%$ for C4 crops [2] [22] [23].

However, response to high $\left[\mathrm{CO}_{2}\right]$ differs from one species to another due to above and below ground environmental conditions. The interactive effects of increasing $\left[\mathrm{CO}_{2}\right]$ with growth influencing factors may alter the plant structure and productivity [4] [24] [25] and have a greater impact on agriculture, affecting both growth and development of crops and ultimately impacting yield and food production [7] [8]. The effect of [ $\left.\mathrm{CO}_{2}\right]$ enrichment on crops varies under different soil moisture regimes [26]. Most studies were carried out under favorable water conditions [27] [28]. However, data on the interactive effects of $\left[\mathrm{CO}_{2}\right]$ and soil moisture on plants are scarce and often contradictory [28]. Many controlled environment studied the effects and interactions of these climate change factors on plants [29], which showed alterations in physiology, growth and development in many crops [30] [31]. Therefore, knowledge of vegetative responses should aid in ascertaining how environmental factors affect the phenology, growth and development of soybean plants along with genotypic response to cope with global climate change.

Soybean (Glycine max (L.) Merrill) is grown primarily for oil extraction and for use as a high protein meal for animal feed [32]. The world population is increasing, and to achieve food and nutritional security, crop productivity should be increased. The soybean plants show a series of changes in their morphology, physiology and biochemistry, negatively affecting their growth, which can reduce productivity by 50\% [33] in various parts of the world where two thirds of world food production is through cultivation under water stress [34]. The relative plasticity of soybean growth and development to the projected abiotic factors will play a major role in determining future responses to a changing climate. Understanding soybean responses to these future climate changes and multiple climate stress factors is needed to develop suitable management and cultural practices to cope with these changes. Most of the abiotic stresses, whether alone or in combination with other factors at any stage of the plants life cycle, can result in loss of yield due to effects on plant physiological processes. This controlled environment rhizotron study documents the effect of elevated $\left[\mathrm{CO}_{2}\right]$ with soil moisture levels on phenology, vegetative growth and yield parameters of soybean plants.

\section{Materials and Methods}

\subsection{Environment and Treatments}

The experiment was conducted at USDA-ARS National Laboratory for Agriculture and Environment (NLAE) in Ames, Iowa, USA under controlled environmental conditions in rhizotron chambers. The dimension of each soil monolith is 1 by 1 by $1.5 \mathrm{~m}$ deep and the soil type is Monona silt loam soil (fine-silty, mixed mesic Typic Hapludoll) from southwestern Iowa [35]. Each rhizotron growth chamber consists of three soil monoliths. Chambers are similar to a standard plant growth chamber and have microprocessor control of temperature, humidity, and lighting such that specific diurnal, weekly, and seasonal environmental patterns can be programmed. Soil water content of the monoliths also can be monitored and controlled.

Treatment consists of two levels of $\left[\mathrm{CO}_{2}\right]$ concentration $\left(380\right.$ and $800 \mu \mathrm{mol} \mathrm{mol}^{-1}$ ) and three soil moisture levels (Low, Normal and High) were studied. Each rhizotron chambers was assigned with a particular level of $\left[\mathrm{CO}_{2}\right]$ concentration where one chamber with ambient $\left[\mathrm{CO}_{2}\right]$ level of $380 \mu \mathrm{mol} \mathrm{mol}{ }^{-1}$ and another with elevated $\left[\mathrm{CO}_{2}\right]$ level of $800 \mu \mathrm{mol} \mathrm{mol}{ }^{-1}$. In each rhizotron chamber, three soil moisture regimes viz., low (5 mm), normal $(7.5 \mathrm{~mm})$ and high $(10 \mathrm{~mm})$ were imposed. Soybean genotypes namely S21-N6 was planted in each soil moisture level (soil monolith) at $60 \mathrm{~cm}$ between two rows by opening small furrow of $5 \mathrm{~cm}$ depth and placing soybean seeds at $10 \mathrm{~cm}$ apart on 25 October 2011. After sowing, each soil monolith was irrigated to $80 \%$ field water capacity (FWC) and uniform soil moisture was maintained in the entire soil profile by daily watering for initial 15 days after planting (DAP) since these rhizotron monoliths were dry before. Two rhizotron chambers were maintained at maximum temperature of $25^{\circ} \mathrm{C}$ and minimum of $15^{\circ} \mathrm{C}$, and at $380 \mu \mathrm{mol} \mathrm{mol}^{-1}\left[\mathrm{CO}_{2}\right] \mathrm{until}^{50 \%}$ 
seedling emergence. Environmental variables; $\left[\mathrm{CO}_{2}\right]$ concentration, temperature and light intensity inside each chambers were continuously monitored and temperature and light were automatically adjusted by the computer to simulate diurnal variations typical of a day. Temperature and light intensity were programmed to be the same between chambers. Only $\left[\mathrm{CO}_{2}\right]$ was varied between chambers, one with ambient $\left[\mathrm{CO}_{2}\right]$, and another with elevated $\left[\mathrm{CO}_{2}\right]$. The environmental sensors and controlling systems of the two chambers were calibrated before the commencement of the experiment and environmental variables were continually monitored at one minute samples and 15 minutes averages during the entire course of experiment in order to minimize the variance induced by the chamber heterogeneity of environmental conditions.

The soil moisture treatments were imposed as low $(5 \mathrm{~mm})$, normal $(7.5 \mathrm{~mm})$ and high $(10 \mathrm{~mm})$ from 15 DAP (8 November 2011) with watering twice during a week (Friday and Tuesday). Elevated $\left[\mathrm{CO}_{2}\right]$ level was maintained in one of the chamber after $50 \%$ seedling emergence by automatically injecting $\left[\mathrm{CO}_{2}\right]$ into the chamber and the level in the chambers was controlled using a $\left[\mathrm{CO}_{2}\right]$ delivery system and chamber vents. An individual LICOR infrared gas analyzer (LI-800 Gas Hound $\left[\mathrm{CO}_{2}\right]$ Analyzer, LI-COR, NE, USA) was used to monitor $\left[\mathrm{CO}_{2}\right]$ levels at each chamber independently.

\subsection{Plant Measurements}

Soybean response to elevated $\left[\mathrm{CO}_{2}\right]$ with soil moisture regimes was assessed at V-3/V-4 (29 DAP), V-6 stage (44 DAP) and at R3 (58 DAP) stage of the soybean crop growth. Above and below ground growth measurements were assessed by periodical destructive growth analysis of two plants from each row in the first two samples and five plants from each row at the final sampling. The above ground growth variables included number of leaves, leaf area, fresh and dry weight of leaves and shoot. The root fresh and dry weight was recorded for each plant. The fresh and dry weights of the samples were recorded following standard procedures. Leaf area was measured using the LI-3100 leaf area meter (LI-COR, Lincoln, NE). Number of pods and dry weight of pods were recorded from each plants at 58 DAP. All component dry weights were obtained following oven-drying to constant weight at $65^{\circ} \mathrm{C}$. Specific leaf weight (SLW) was calculated as leaf weight/leaf area [36]. Dried leaf samples were ground and sieved for analysis of nitrogen and carbon. Organic carbon content was estimated by wet digestion following the modified method of [37] and expressed as percent on dry weight basis. For total nitrogen analysis, the samples were digested by the Kjeldahl method and analyzed with an auto analyzer (Technicon, USA).

\subsection{Statistical Analysis}

Statistical analysis was conducted by using of variance (ANOVA) (Web Based Agricultural Statistics Software Package (WASP-2). Effects of $\left[\mathrm{CO}_{2}\right]$ levels, soil moisture levels and interactions were tested, using the least significant difference tests at $\mathrm{P}=0.05$ and 0.01 . The data at each observational date were analyzed separately and results are presented in tabular and graphical representation with the standard error bars.

\section{Results}

\subsection{Phenology of Crop}

At early crop growth stage of soybean, growth and phenology of crop was affected by $\left[\mathrm{CO}_{2}\right]$ and soil moisture (Figure 1). Plants showed slow crop growth rate and delayed phenology under elevated $\left[\mathrm{CO}_{2}\right]$ compared to ambient $\left[\mathrm{CO}_{2}\right]$. Plants under elevated $\left[\mathrm{CO}_{2}\right]$ showed V-3 (83\%) and V-6 (50\%) growth stage against V-4 (50\%) and R-3 (58\%) stages under ambient $\left[\mathrm{CO}_{2}\right]$ at 29 and 44 DAP, respectively. Effect of soil moisture was highly significant at 29 DAP where in growth rate was increases with increase in soil moisture contents (Figure 1). At 29 DAP all the plants under low soil moisture showed slow growth (V-6) than plants under normal and high soil moisture levels and observed greater number of R-3 soybean plants with increased soil moisture levels. At later stage (44 DAP) phenology was not significant but $50 \%$ of soybean plants of V-6 and R-3 growth stage under low soil moisture against greater numbers of plants showed V-6 growth stage under normal and high soil moisture levels (Figure 1). However, no significant interactions effect was observed on phenology of soybean.

\subsection{Vegetative Growth Parameters}

\subsubsection{Shoot Height}

Shoot height was significant at 29 and 44 DAP for $\left[\mathrm{CO}_{2}\right]$ levels and plants under ambient $\left[\mathrm{CO}_{2}\right]$ had 2.8 and 


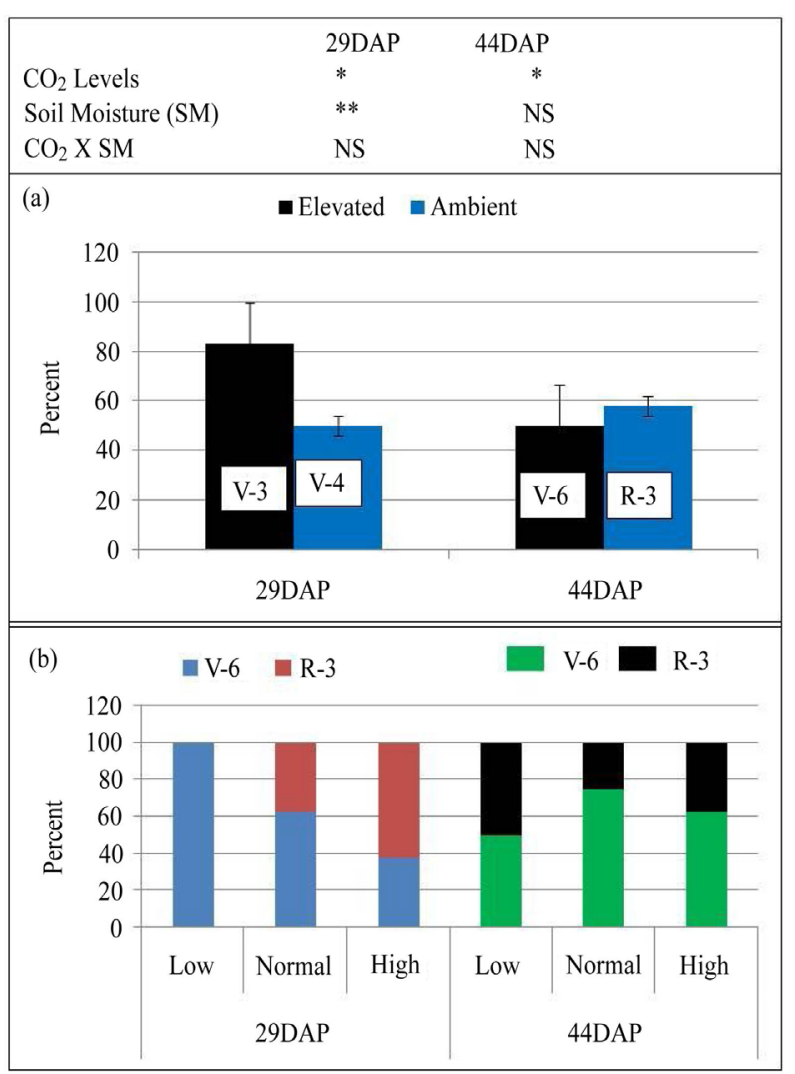

Figure 1. Carbon dioxide (a) and soil moisture levels (b) on phenology of soybean plants at 29 and 44 DAP (* and **: Significant at $0.05 \%$ and $0.01 \%$ P, respectively; NS: Not significant; Low, Normal and High are soil moisture levels).

$15.9 \mathrm{~cm}$ greater shoot height than plants under elevated $\left[\mathrm{CO}_{2}\right]$ (Table 1). On the other hand, shoot height was significantly high when plants grown with normal soil moisture at 44 and 58 DAP. Interaction effects of $\left[\mathrm{CO}_{2}\right]$ and soil moisture was significant on shoot height at early growth (V-3 \& V-4) stage of crop (29 and 44 DAP).

\subsubsection{Leaf Growth Parameters}

At early stage of soybean, plants under high $\left[\mathrm{CO}_{2}\right]$ significantly affected the leaf number and leaf area due to inhibited slow growth rate of plants. Under elevated $\left[\mathrm{CO}_{2}\right]$ decreases number of leaves by $23 \%$ and $14 \%$ and there by reduction in leaf area by $11.7 \%$ and $9.7 \%$ compared to ambient $\left[\mathrm{CO}_{2}\right]$ at 29 and $44 \mathrm{DAP}$, respectively (Table 1). However, due to adaptive mechanism of plants to high $\left[\mathrm{CO}_{2}\right]$ produced $39 \%$ and $83.7 \%$ greater leaf number and leaf area, respectively at later stage (R-3) of the crop growth (59 DAP). Soil moisture and genotypes effect on number of leaf and leaf area was not significant and showed inconsistence results during the study period. On the other hand, interactive effect of $\left[\mathrm{CO}_{2}\right]$ and soil moisture significant at early growth stage (29 DAP), plants under ambient $\left[\mathrm{CO}_{2}\right]$ with high soil moisture produced greater leaf number and leaf area.

\subsubsection{Specific Leaf Area (SLA)}

SLA which is an indicator of leaf thickness, showed significant decrease at 29 DAP (22.2\%) but marginal increase at $44(1.4 \%)$ and 58 DAP $(8.5 \%)$ under elevated $\left[\mathrm{CO}_{2}\right]$ (Figure 2). Increases in SLA was observed with increase in soil moisture status but was significant at only 29 DAP. However, interactive effect of elevated $\left[\mathrm{CO}_{2}\right]$ and soil moisture was significant at early stage.

\subsection{Dry matter Accumulation}

Leaf, shoot and total dry matter production of plants was significantly greater under elevated $\left[\mathrm{CO}_{2}\right]$ at $58 \mathrm{DAP}$ 
Table 1. Plant height $(\mathrm{cm})$, number of leaves and leaf area per plants under elevated $\left[\mathrm{CO}_{2}\right]$, soil moisture levels (Low, Normal \& High) and their interactions effects $(\mathrm{P}<0.05)$.

\begin{tabular}{|c|c|c|c|c|c|c|c|c|c|}
\hline Treatment & & Height (cm) & & \multicolumn{3}{|c|}{ No. of Leaves } & \multicolumn{3}{|c|}{ Leaf Area $\left(\mathrm{cm}^{2}\right)$} \\
\hline \multicolumn{10}{|c|}{ Days After Planting } \\
\hline & 29 & 44 & 58 & 29 & 44 & 58 & 29 & 44 & 58 \\
\hline \multicolumn{10}{|c|}{$\mathrm{CO}_{2}$ Level (A) } \\
\hline Elevated (EC) & 15.2 & 78.0 & 96.0 & 5.8 & 16.2 & $33.8^{* *}$ & 143 & 626 & $1475^{*}$ \\
\hline Ambient (AC) & $18.0^{* *}$ & $93.9^{* *}$ & 101.0 & $7.1^{*}$ & 18.4 & 24.3 & 160 & 687 & 803 \\
\hline \multicolumn{10}{|c|}{ Soil Moisture Level (B) } \\
\hline Low & 15.7 & 78.4 & 97.5 & 5.5 & 17.3 & 28.5 & 137 & 667 & 1262 \\
\hline Normal & 18.0 & $94.6^{*}$ & $107.3^{*}$ & 6.5 & 18.9 & 31.9 & 155 & 705 & 1206 \\
\hline High & 16.1 & 84.9 & 90.7 & 7.3 & 15.8 & 26.8 & 163 & 598 & 950 \\
\hline \multicolumn{10}{|c|}{ Interaction Effect $(P$ Values $<\mathbf{0 . 0 5})$} \\
\hline $\mathrm{AXB}$ & 0.003 & 0.013 & 0.652 & 0.01 & 0.970 & 0.018 & 0.003 & 0.884 & 0.53 \\
\hline
\end{tabular}

* Significant at $\mathrm{P}=0.05 ;{ }^{* *}$ Significant at $\mathrm{P}=0.01$.

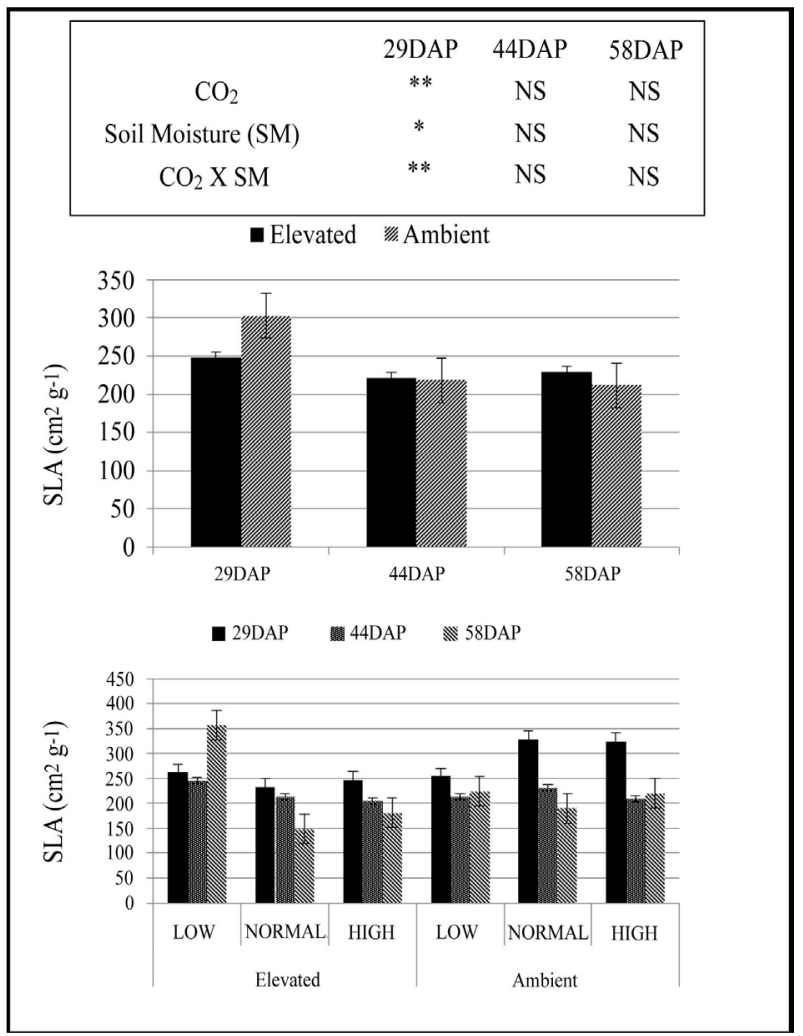

Figure 2. Specific leaf area (SLA) of soybean leaf under $\left[\mathrm{CO}_{2}\right]$ and soil moisture levels (Low, Normal and High) $(*$ and $* *$ : Significant at 0.05 and $0.01 \% \mathrm{P}$, respectively; NS: Not significant). (Elevated and Ambient are $\mathrm{CO}_{2}$ levels; Low, Normal and High are soil moisture levels).

(R-3). Dry matter accumulation in different parts of plant was marginally greater under elevated $\left[\mathrm{CO}_{2}\right]$ at 29 DAP but at 44 DAP, elevated $\left[\mathrm{CO}_{2}\right]$ failed to produce grater dry matter (Table 2). Plants under elevated $\left[\mathrm{CO}_{2}\right]$ produced $93.76 \%, 83.5 \%$ and $56 \%$ greater dry matter in leaves, shoot and total, respectively at 58 DAP. Similarly, plants with normal soil moisture conditions produced greater dry matter at all the stages but statistically it was significantly greater at 58 DAP. However, genotypes not responded significantly to the $\left[\mathrm{CO}_{2}\right]$ and soil 
Table 2. Soybean plant component wise dry matter accumulation under elevated $\left[\mathrm{CO}_{2}\right]$, soil moisture levels (Low, Normal \& High) and their interactions effects $(\mathrm{P}<0.05)$.

\begin{tabular}{|c|c|c|c|c|c|c|c|c|c|}
\hline Treatment & \multicolumn{3}{|c|}{ Leaf (g plant $\left.{ }^{-1}\right)$} & \multicolumn{3}{|c|}{ Stem $\left(\right.$ g plant $\left.^{-1}\right)$} & \multicolumn{3}{|c|}{ Total Dry Weight $\left(\right.$ g plant $^{-1}$ ) } \\
\hline \multicolumn{10}{|c|}{ Days After Planting } \\
\hline & 29 & 44 & 58 & 29 & 44 & 58 & 29 & 44 & $58^{\#}$ \\
\hline \multicolumn{10}{|c|}{$\mathrm{CO}_{2}$ Level (A) } \\
\hline Elevated & 0.57 & 2.81 & $7.46^{* *}$ & 0.26 & 1.82 & $4.66^{* *}$ & 0.95 & 5.07 & $17.0^{* *}$ \\
\hline Ambient & 0.52 & 3.14 & 3.85 & 0.25 & 2.24 & 2.54 & 0.89 & 5.87 & 10.9 \\
\hline \multicolumn{10}{|c|}{ Soil Moisture Level (B) } \\
\hline Low & 0.53 & 2.91 & 4.37 & 0.24 & 1.91 & 2.84 & 0.89 & 5.28 & 11.63 \\
\hline Normal & 0.54 & 3.18 & $7.70^{* *}$ & 0.27 & 2.31 & $4.87^{* *}$ & 0.94 & 6.01 & $18.22^{* *}$ \\
\hline High & 0.57 & 2.83 & 4.89 & 0.25 & 1.86 & 3.12 & 0.92 & 5.12 & 12.14 \\
\hline \multicolumn{10}{|c|}{ Interaction Effect $(P$ Values $<0.05)$} \\
\hline $\mathrm{AXB}$ & 0.03 & 0.921 & 0.003 & 0.004 & 0.976 & 0.036 & 0.014 & 0.971 & 0.022 \\
\hline
\end{tabular}

* Significant at $\mathrm{P}=0.05 ;{ }^{* *}$ Significant at $\mathrm{P}=0.01 ;{ }^{*}$ Excluding roots.

moisture levels. Interactive effect of $\left[\mathrm{CO}_{2}\right]$ and soil moisture was statistically significant at 29 and 58 DAP. Due to the slow growth of plants under elevated $\left[\mathrm{CO}_{2}\right]$ at early stage contributed marginal increases in dry matter production in different components of plants.

\subsection{Leaf Carbon and Nitrogen Contents}

Increase in percent carbon content and decrease in percent nitrogen content in the leaves under elevated $\left[\mathrm{CO}_{2}\right]$ grown plants (Figure 3). The organic carbon content, which constitutes both structural and non-structural components, increased marginally $(<1 \%)$ in plants grown under elevated $\left[\mathrm{CO}_{2}\right]$. This might be due to slow and delayed growth of plants at early stage under elevated $\left[\mathrm{CO}_{2}\right]$ contributed marginal gain in organic carbon content in leaf compared to plants under ambient $\left[\mathrm{CO}_{2}\right]$. A reduction of $6 \%$ and $9.5 \%$ in nitrogen content was observed at 29 and 44 DAP, respectively. The increase in carbon concentration and reduction in nitrogen concentration increased the $\mathrm{C}: \mathrm{N}$ ratio of soybean leaves, which was the highest $(12.98 \%)$ at $44 \mathrm{DAP}$ followed by $4.4 \%$ at 29 DAP when plants enriched with $\left[\mathrm{CO}_{2}\right]$. However, interactive effects of elevated $\left[\mathrm{CO}_{2}\right]$ and soil moisture was significant for leaf nitrogen content and $\mathrm{C}: \mathrm{N}$ ratio at 44DAP.

\subsection{Number of Pods and Pods Dry Weight}

Plants under elevated $\left[\mathrm{CO}_{2}\right]$ produced significantly higher number of pods by $54.7 \%$ and contributed greatly for increase in dry weight of pods by $6.9 \%$ compared to plants under ambient $\left[\mathrm{CO}_{2}\right]$ (Figure 4). On the other hand, plants with normal soil moisture condition produced maximum number of pods which was greater by $45.4 \%$ and $28.9 \%$ and this contributed towards increase in dry weight of pods by $27.7 \%$ and $36.8 \%$ compared to low and high soil moisture conditions, respectively. Interaction effect of $\left[\mathrm{CO}_{2}\right]$ and soil moisture levels found significant on number of pods. Plants under elevated $\left[\mathrm{CO}_{2}\right]$ with normal soil moisture condition produced maximum number of pods by $54.8 \%$ and $122.4 \%$ compared to elevated $\left[\mathrm{CO}_{2}\right]$ with high soil moisture and ambient $\left[\mathrm{CO}_{2}\right]$ with low soil moisture condition, respectively.

\subsection{Number of Root Nodules}

Plants under elevated $\left[\mathrm{CO}_{2}\right]$ produced significantly greater number of root nodules per plant by $114 \%$ compared to plants under ambient $\left[\mathrm{CO}_{2}\right]$ at 44 DAP (Figure 5). On the other hand, plants with normal soil moisture condition produced greater number of root nodules per plant which was greater by $42 \%$ and $155.5 \%$ compared to low and high soil moisture conditions, respectively. Interaction effect of $\left[\mathrm{CO}_{2}\right]$ and soil moisture levels was not significant on number of nodules.

\section{Discussion}

\subsection{Effect of Elevated $\mathrm{CO}_{2}$ on Phenology}

In the present experiment $\left[\mathrm{CO}_{2}\right]$ enrichment altered phenology of plants at early stage of soybean. This agrees 


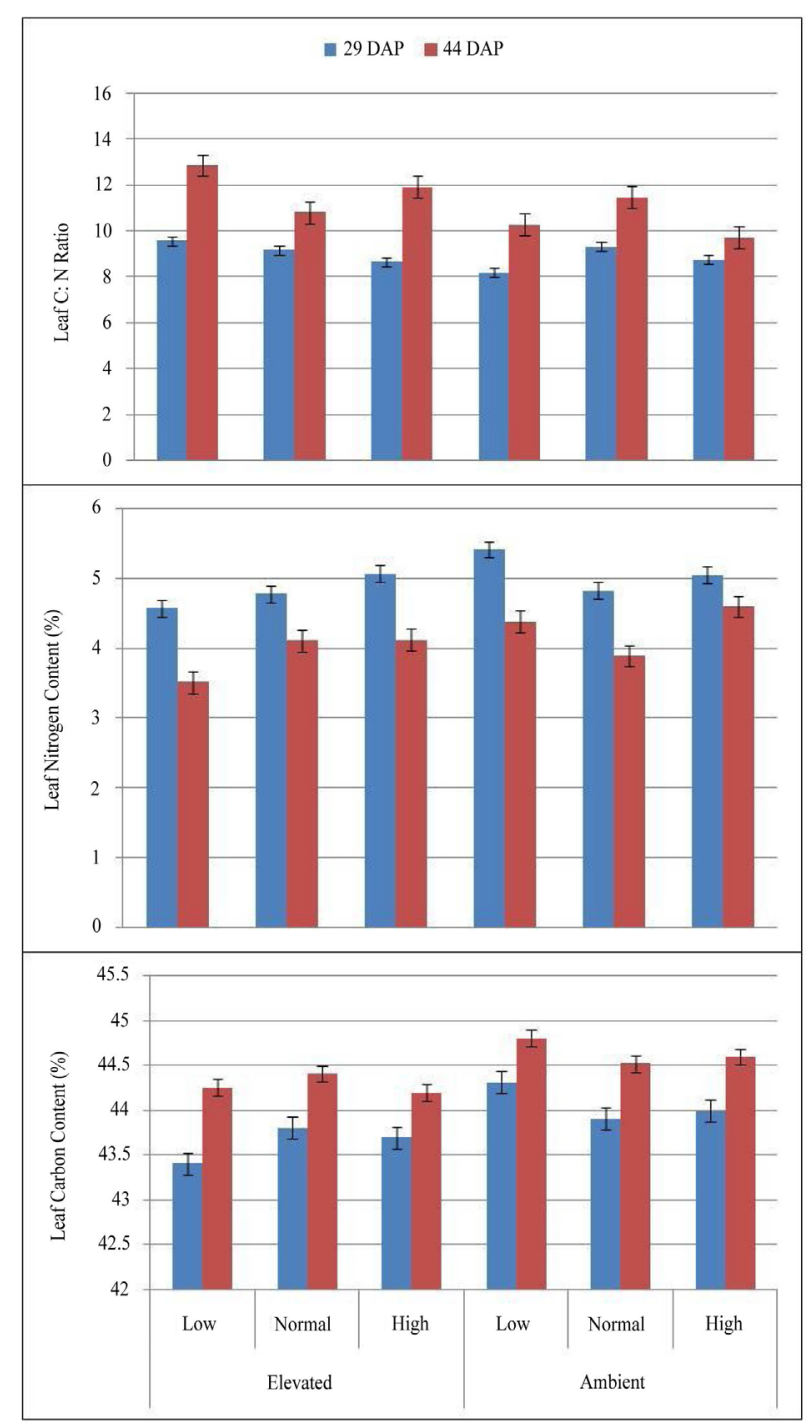

Figure 3. Carbon dioxide (Elevated and Ambient) and soil moisture content levels (Low, Normal and High) on leaf organic carbon, nitrogen and C:N ratio of soybean at 29 and 44 DAP.

many with the results of previous studies of [38] and [39] and contradicts the findings of [40] where they reported that vegetative stages slightly faster and the number of nodes was slightly greater with increased $\left[\mathrm{CO}_{2}\right]$ (160 to $\left.990 \mu \mathrm{mol} \mathrm{mo}^{-1}\right)$ at early stage but after 52 days, plants in all treatments had reached the same reproductive stage. Results of many studies on phenology of soybean was inconsistence and reported that plants under above ambient $\left[\mathrm{CO}_{2}\right]$ had no effect [41]-[43], decreased [38] [39], or increased time to flowering [44]-[46]. Plants phenology and growth greatly influenced by temperature than elevated $\left[\mathrm{CO}_{2}\right]$ [47]. The phenological development of soybean is common with the major temperate crops and plants require a certain amount of heat units (thermal time i.e., GDD) to reach each physiological development stage. At warmer temperatures, plants achieve these requirements earlier, thus enhancing physiological development in most plants. Long-term exposure to elevated $\left[\mathrm{CO}_{2}\right]$ in soybean [48] and dry bean [43] increased leaf temperature by about $2^{\circ} \mathrm{C}$ compared to those at ambient $\left[\mathrm{CO}_{2}\right]$ at temperature ranging from $28^{\circ} \mathrm{C} / 18^{\circ} \mathrm{C}$ to $40^{\circ} \mathrm{C} / 30^{\circ} \mathrm{C}$. Elevated $\left[\mathrm{CO}_{2}\right]$ induced increased leaf temperature might be the primary major contributing reason for change in phenology of soybean. In the present study, high $\left[\mathrm{CO}_{2}\right]$ might have inhibited the growth at early stage of crop but due to adoptive mechanism of plants to high $\left[\mathrm{CO}_{2}\right]$ plants were recovered and responded physiologically at later stage. Interactions effects of climate change factors on plants was studied by [29] and reported alterations both in physiology and growth and 


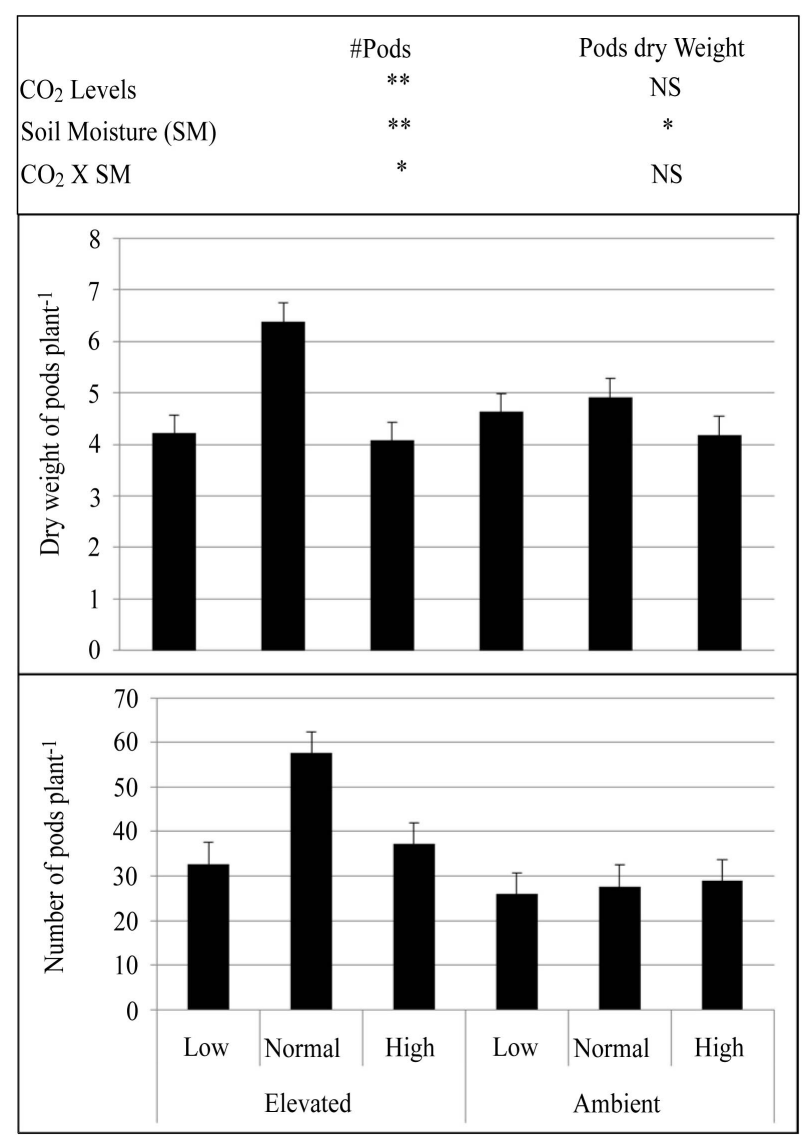

Figure 4. Carbon dioxide (Elevated and Ambient) and soil moisture levels (Low, Normal and High) on number of pods and pods dry weight of soybean (* and **: Significant at 0.05 and $0.01 \%$ P, respectively; NS: Not significant).
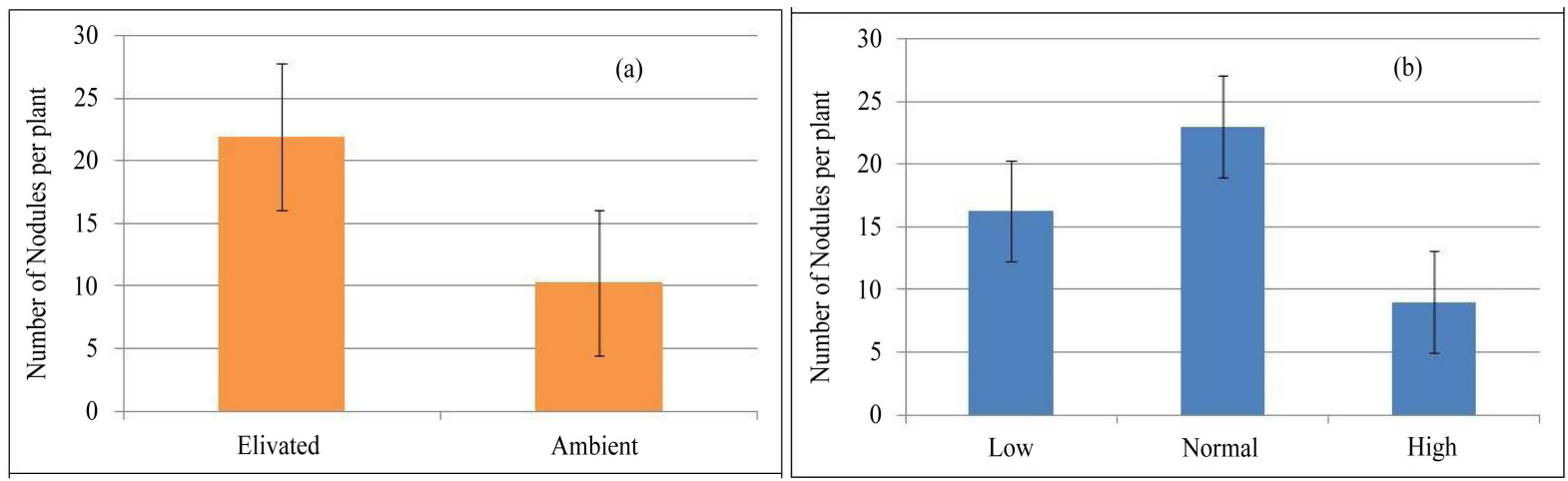

Figure 5. Carbon dioxide (a) and soil moisture levels (b) on number of root nodules of soybean at 44DAP $\left({ }^{* *} \mathrm{P}<0.014\right.$ and ${ }^{*} \mathrm{P}<0.048$ for $\mathrm{CO}_{2}$ and soil moisture levels, respectively).

development in crops such as soybean [30], cotton [31] and many other crops due to $\left[\mathrm{CO}_{2}\right]$ enrichment. From a practical viewpoint, the altered crop duration and phenology due to rising $\left[\mathrm{CO}_{2}\right]$ may exposes the crop plants to a higher risk from frost [49], biotic and abiotic stress, and other environmental anomalies.

\subsection{Effect of Elevated $\mathrm{CO}_{2}$ on Vegetative Growth Parameters}

Our results on shoot height of soybean contradicting to the previous results reported by [39] and [44] and they 
concluded that increase in main stem height of soybean was attributed to increased node number and stimulation of internodes elongation under $\left[\mathrm{CO}_{2}\right]$ enrichment. In another study, high $\left[\mathrm{CO}_{2}\right]$ enhanced plants lateral growth more than vertical growth in wheat as reported by [47] [50]. Decreased shoot height at early growth stage of soybean under elevated $\left[\mathrm{CO}_{2}\right]$ was attributed to slow growth rate and altered penology of plants. This result in conformity with the previous results of decreased in growth under high $\left[\mathrm{CO}_{2}\right]$ reported by [39] and [51]. The existing literature on vegetative growth response to elevated $\left[\mathrm{CO}_{2}\right]$ is very limited and results differ considerably suggesting further studies to understand interactive effects of soil moisture, nutrients and genotype.

The results of the current experiment on number of leaf and leaf area at early stage of crop growth contradict to the previous studies. An increase in the number of leaves has been reported in Japanese honey-suckle [52] in sweet potato [45] and in berseem [53] under elevated $\left[\mathrm{CO}_{2}\right]$. Increase in leaf area under $\left[\mathrm{CO}_{2}\right]$ enrichment has been reported in soybean by [39] and [54], in berseem by [53]. Our results showed positive correlation between leaf number and leaf area $\left(0.858^{*}, 0.897^{*}\right.$ and $0.401^{*}$, at 29,44 and $59 \mathrm{DAP}$, respectively).Decrease in number of leaf and leaf area under high $\left[\mathrm{CO}_{2}\right]$ at early stage might be attributed to inhibited and slow growth of plants but greater response of plants at later stage may be due to adoptive mechanism of plants.

Our experimental results indicates that exposure to elevated $\left[\mathrm{CO}_{2}\right]$ caused an initial increase in leaf thickness due to increased number of palisade cells is an extra layer of cells, which contributed to leaf thickness [55] but at later stages further expansion of the leaves resulted in thinner leaves. Reduction in leaf thickness has been reported in various crop species such as soybean [56] and beans [57] but increased specific leaf weight (SLW) of soybean reported by many earlier studies [57]-[59]. The reduction of leaf thickness was also due to less accumulation of starch and a faster rate of leaf expansion. Plants responsiveness to $\left[\mathrm{CO}_{2}\right]$ enrichment was differ considerably between different locations, with a large proportion of the observed variability remaining unexplained. This suggests that plant morphology may be somewhat altered under future high $\left[\mathrm{CO}_{2}\right]$ conditions [60]-[64].

\subsection{Effect of Elevated $\mathrm{CO}_{2}$ and Soil Moisture on Dry Matter Production}

Our results on dry matter accumulation in different parts of plant was marginally greater under elevated $\left[\mathrm{CO}_{2}\right]$ at 29 DAP but significantly greater under at 58 DAP (R-3). Our results on dry matter production in agreement with many previous studies on different crops showed increase in total dry matter production of soybean [38] [65][67], dry bean [43], peanut [68] [69], and cowpea [42] [45] [46] [70] under $\left[\mathrm{CO}_{2}\right.$ ] enrichment. However, greater dry matter accumulation when plants under elevated $\left[\mathrm{CO}_{2}\right]$ at later stage was attributed due to the partitioning of greater amounts of assimilated carbon towards the growing organs. Earlier studies also showed that the extra carbon fixed by the plants due to $\left[\mathrm{CO}_{2}\right]$ enrichment translocate to the growing axis [71]. An increase in biomass due to increase in the number of branches/leaves has also been reported in many crops under $\left[\mathrm{CO}_{2}\right]$ enrichment [45] [52]. The interactive effect of $\left[\mathrm{CO}_{2}\right]$ enrichment on crops varies under different soil moisture regimes [26], but many studies were carried out under favorable soil moisture conditions [27] [28]. However, data on the interactive effects of $\left[\mathrm{CO}_{2}\right]$ and soil moisture on plants are limited and often contradictory [28]. Some authors claim that the percentage increase in plant growth due to elevated $\left[\mathrm{CO}_{2}\right]$ is generally not reduced by water stress [72][74] whereas the results of many other theoretical projections and field or greenhouse experiments suggest that the relative effects of $\left[\mathrm{CO}_{2}\right]$ enrichment on plants are constrained by less than optimal levels of soil moisture [14] [24] [75]-[81].

\subsection{Effect of Elevated $\mathrm{CO}_{2}$ and Soil Moisture on Leaf Carbon and Nitrogen Content}

The results of this study indicated that, plants enriched with $\left[\mathrm{CO}_{2}\right]$ increases the leaf carbon concentration and reduction in nitrogen concentration increased the $\mathrm{C}: \mathrm{N}$ ratio of soybean leaves. Previous studies also reported reduction in leaf nitrogen concentration with elevated $\left[\mathrm{CO}_{2}\right]$ in different crop species [12]-[14] [82]. This reduction in nitrogen may be either due to the dilution effect as a result of greater carbohydrate accumulation [13] or due to the acceleration of plant growth, but not due to the increased nitrogen use efficiency [83]. Our study suggests that the reduction in leaf nitrogen might due to increase in leaf area as a result of extra carbon fixed by higher photosynthesis and lack of proportionate gain in nitrogen uptake by the plants. Uptake of nitrogen may also be reduced at high $\left[\mathrm{CO}_{2}\right]$ due to lower transpiration rates [11] [84] [85]. The decrease in tissue $\mathrm{N}$ concentration also due to reduction in the Rubisco content, decreased uptake of minerals from soil because of reduction in stomatal conductance, less water uptake by plants [86], and decrease in the rate of assimilation of $\mathrm{NO}_{3}{ }^{-}$into organic compounds [87]. The reduction in leaf $\mathrm{N}$ concentration can be substantial varying from $10 \%$ to $31 \%$ [88]. 
Increased biomass in elevated $\left[\mathrm{CO}_{2}\right]$ is not always supplemented by an increase in the concentration of essential nutrient elements. Reduction in nutrient concentration of plants due to increased $\left[\mathrm{CO}_{2}\right]$ concentration has been reported by earlier studies [10]-[12]. The reason attributed to the uptake of nutrient from the soil is not increased in relation to the increased net carbon assimilation may leading to changes in the nutritional quality of the crops. High $\mathrm{C}: \mathrm{N}$ ratio due to elevated $\left[\mathrm{CO}_{2}\right]$ has been reported in various investigations [15] [16]. On the other hand no significant effect of soil moisture and the interactions was found on carbon, nitrogen and $\mathrm{C}: \mathrm{N}$ ratio of soybean leaf. The interaction effect of elevated $\left[\mathrm{CO}_{2}\right]$ and soil moisture levels on the elemental compositions of crops, especially on essential elements, should receive more attention, because there has been a great dearth of literature on this aspect.

\subsection{Effect of Elevated $\mathrm{CO}_{2}$ and Soil Moisture on Pods}

Plants under elevated $\left[\mathrm{CO}_{2}\right]$ produced significantly higher number of pods and contributed greatly for increase in dry weight of pods. Our results in agreement with the several earlier studies where they reported $\left[\mathrm{CO}_{2}\right]$ enriched plants likely to produce more and larger flowers, as well as induce other flower-related changes bearing significant implications on plant productivity [17]-[21] [89]-[92]. The extra carbon assimilates produced at high $\left[\mathrm{CO}_{2}\right]$ may ensure the full development of flowers and grains [93]. Further previous studies on $\left[\mathrm{CO}_{2}\right]$ enrichment reported that, increases in strawberry yield with an increase in fruit number [94], yield response of barley [78] and orange [95] related to the number of grain and fruits harvested, increase in the number of flower buds in cotton [13] and increase in broad bean yield by increase in bean number [81].

\subsection{Effect of Elevated $\mathrm{CO}_{2}$ and Soil Moisture on Root Nodules}

The result showed that, plants under elevated $\left[\mathrm{CO}_{2}\right]$ and normal soil moisture level produced significantly greater number of root nodules. This finding is in agreement with the several earlier studies where they reported $\left[\mathrm{CO}_{2}\right]$ enriched plants likely to produce more number of root nodules [96]-[98]. Enhanced photosynthetic carbon fixation under elevated $\left[\mathrm{CO}_{2}\right]$ will provide more \& additional energy for microbial activity and facilitate nitrogen fixation in legumes. Earlier studies also reported that, symbiosis between legume and bacteria was greater under elevated $\left[\mathrm{CO}_{2}\right][99]$ [100] and increased nodule number per plant and nodule dry weight [101] [102]. Gray et al. (2013) [103] found that nodule numbers were $134 \%$ - 229\% greater in soybeans grown at elevated $\left[\mathrm{CO}_{2}\right]$ in combination with reduced precipitation, and this response was driven by greater nodule density per unit of root length. Soil moisture also plays vital role in development of nodules since $\mathrm{N}_{2}$-fixation is sensitive to soil moisture than the carbon assimilation but the magnitude of the reduction in $\mathrm{N}_{2}$ fixation depends on the severity of the drought stress as well as the timing of the drought stress relative to plant growth and development [104]. In our study reduction in number of nodules was greater under low and high soil moisture condition. Antolín et al. (2010) [105] also found reduced nodule numbers under drought condition. This increased in number of nodules probably also due to allocation of additional photosynthates produced due to elevated $\left[\mathrm{CO}_{2}\right]$ to root and nodules development. Kimball (1985) [106], suggested that leguminous crops will probably not be nitrogen limited in future climates with elevated $\left[\mathrm{CO}_{2}\right]$ any more than they are at present $\left[\mathrm{CO}_{2}\right]$.

\subsection{Interactive Effect of Elevated $\mathrm{CO}_{2}$ and Soil Moisture}

The results from the present study provide evidence for individual and interactive effects of two very important environmental factors viz., $\left[\mathrm{CO}_{2}\right]$ and soil water that are projected to change in the future climate on soybean growth and development in the world. Plant response to $\left[\mathrm{CO}_{2}\right]$ was shown differ considerably between different locations, crops/genotypes etc., and interaction effect with soil water or temperature a large proportion of the observed variability remaining unexplained. Overall, our study reveals that the interaction effect of elevated $\left[\mathrm{CO}_{2}\right]$ and normal soil moisture was significant for the growth and yield related parameters only at later stage of crop (58 DAP). The effect of $\left[\mathrm{CO}_{2}\right]$ enrichment on crops varies under different soil moisture regimes as reported by [26]. At plant canopy level, high $\left[\mathrm{CO}_{2}\right]$ can alleviate the negative effect of water deficit on plants due to decreased transpiration and conductance but at plant-soil level, the positive effect of high $\left[\mathrm{CO}_{2}\right]$ on plant growth was constrained by less favorable moisture conditions in soil. This is supported with many previous studies [28] [81] [107]-[109]. However, data on the interactive effects of $\left[\mathrm{CO}_{2}\right]$ and soil moisture on plants are scarce and often contradictory [28]. Some studies reported that the percentage increase in plant growth due to elevated $\mathrm{CO}_{2}$ 
is generally not reduced by water stress [73] [74] whereas the results of many other theoretical projections and field or greenhouse experiments suggest that the relative effects of $\left[\mathrm{CO}_{2}\right]$ enrichment on plants are constrained by less than optimal levels of soil moisture [14] [78]-[81].

\section{Conclusion}

High $\left[\mathrm{CO}_{2}\right]$ affected the phenology of soybean at early vegetative growth but showed adoptive mechanism in the later stage, and this result suggested further in-depth studies to confirm the feedback of elevated $\left[\mathrm{CO}_{2}\right]$ particularly on crop phenology and its adoptive mechanisum. Observed increases SLA, dry matter content of plants but deceases leaf nitrogen content under elevated $\left[\mathrm{CO}_{2}\right]$. Plants under elevated $\left[\mathrm{CO}_{2}\right]$ produced significantly greater numbers of root nodules per plant compared with plants under ambient $\left[\mathrm{CO}_{2}\right]$ indicating that future plants may be benefited from $\mathrm{N}_{2}$ fixation if other environmental conditions are favorable. Interactive effects of $\left[\mathrm{CO}_{2}\right]$ enrichment and soil moisture on plants greatly depend on soil moisture availability and plants may benefit greatly from future climate change scenario of increased atmospheric $\left[\mathrm{CO}_{2}\right]$ with optimum or sufficient availability of water. Further studies on interactive effect of $\left[\mathrm{CO}_{2}\right]$, soil moisture and nutrients are needed to understand the growth and yield response of important food crops.

\section{Acknowledgements}

The technical support and guidance of all staff of NLAE-USDA laboratory, Iowa State University, Iowa, USA is thankfully acknowledged. This work is supported by the USAID and USDA is gratefully acknowledged under USDA-GRA fellowship program.

\section{Conflict of Interest}

Trade names and company names are included for the benefit of the reader and do not imply any endorsement or preferential treatment of the product by the authors or the USDA-ARS. USDA is an equal opportunity provider and employer.

\section{References}

[1] Kiehl, J. (2011) Lessons from Earth's Past. Science, 331, 158-159. http://dx.doi.org/10.1126/science.1199380

[2] IPCC (2007) Climate Change 2007: The Physical Science Basis. Contribution of Working Group I to the Fourth Assessment Report of the Intergovernmental Panel on Climate Change. Cambridge University Press, Cambridge.

[3] Keeling, R.F. and Piper, S.C. (2009) Atmospheric $\mathrm{CO}_{2}$ Records from Sites in the SIO Air Sampling Network. In: Boden, T.A., Kaiser, D.P., Sepanki, R.J. and Stoss, F.W, Eds, Trends: A Compendium of Data on Global Change, Carbon Dioxide Information Analysis Center, Oak Ridge National Laboratory, U.S. Department of Energy, Oak Ridge, 16-26.

[4] Drake, B.G. (1997) More Efficient Plants: A Consequence of Rising Atmospheric $\mathrm{CO}_{2}$ ? Annals Review of Plant Physiology, 48, 609-639. http://dx.doi.org/10.1146/annurev.arplant.48.1.609

[5] Ulman, P., Catsky, J. and Pospisilova, J. (2000) Photosynthetic Traits in Wheat Grown under Decreased and Increased $\mathrm{CO}_{2}$ Concentration, and after Transfer to Natural $\mathrm{CO}_{2}$ Concentration. Biologia Plantarum, 43, 227-237. http://dx.doi.org/10.1023/A:1002752210237

[6] Srivastava, A.C., Khanna, Y.P., Meena, R.C., Pal, M. and Sengupta, U.K. (2002) Diurnal Changes in Photosynthesis, Sugars, and Nitrogen of Wheat and Mungbean Grown under Elevated $\mathrm{CO}_{2}$ Concentration. Photosynthetica, 40, 221225. http://dx.doi.org/10.1023/A:1021393607410

[7] Cox, P.M., Betts, R.A., Jones, C.D., Spall, S.A. and Totterdell, I.J. (2000) Acceleration of Global Warming Due to Carbon-Cycle Feedbacks in a Coupled Climate Model. Nature, 408, 184-187. http://dx.doi.org/10.1038/35041539

[8] Hansen, W.J., Sato, M., Ruedy, R., Lacis, A. and Oinas, V. (2000) Global Warming in the Twenty-First Century: An Alternative Scenario. Proceedings of National Academy of Science, 97, 9875-9880. http://dx.doi.org/10.1073/pnas.170278997

[9] Srivastava, A.C., Sengupta, U.K. and Pal, M. (2001) Growth, $\mathrm{CO}_{2}$ Exchange Rate and Dry Matter Partitioning in Mungbean Grown under Elevated $\mathrm{CO}_{2}$. Indian Journal Experimental Biology, 39, 572-577.

[10] Overdieck, D. (1993) Elevated $\mathrm{CO}_{2}$ and Mineral Content of Herbaceous and Woody Plants. Vegetation, 104-105, 403411. http://dx.doi.org/10.1007/BF00048169

[11] Manderscheid, R., Bender, J., Jager, H.J. and Weigel, H.J. (1995) Effects of Season Long $\mathrm{CO}_{2}$ Enrichment on Cereals. 
II. Nutrient Concentrations and Grain Quality. Agriculture, Ecosystems \& Environment, 54, 175-185. http://dx.doi.org/10.1016/0167-8809(95)00602-O

[12] Conroy, J.P. (1992) Influence of Elevated Atmosphere $\mathrm{CO}_{2}$ Concentration on Plant Nutrition. Australian Journal of Botany, 40, 445-456.

[13] Rogers, G.S., Milham, P.J., Thibaud, M.C. and Conroy, J.P. (1996) Interaction between Rising $\mathrm{CO}_{2} \mathrm{Concentration} \mathrm{and}^{-}$ Nitrogen Supply in Cotton. I. Growth and Leaf Nitrogen Concentration. Australian Journal of Plant Physiology, 23, 119-125. http://dx.doi.org/10.1071/PP9960119

[14] Ziska, L.H., Manalo, P.A. and Ordonez, R.A. (1996) Intraspecific Variation in the Response of Rice (Oryza sativa L.) to Increased $\mathrm{CO}_{2}$ and Temperature: Growth and Yield Response of 17 Cultivars. Journal of Experimental Botany, 47, 1353-1359. http://dx.doi.org/10.1093/jxb/47.9.1353

[15] Farage, P.K., Mckee, I.F. and Long, S.P. (1998) Does a Low Nitrogen Supply Necessarily Lead to Acclimation of Photosynthesis to Elevated $\mathrm{CO}_{2}$. Plant Physiology, 118, 573-580. http://dx.doi.org/10.1104/pp.118.2.573

[16] Gifford, R.M., Barrett, D.J. and Lutze, J.L. (2000) The Effect of Elevated $\mathrm{CO}_{2}$ on the C: N and C:P Mass Ratio of Plant Tissues. Plant and Soil, 224, 1-14. http://dx.doi.org/10.1023/A:1004790612630

[17] Jablonski, L.M., Wang, X.Z. and Curtis, P.S. (2002) Plant Reproduction under Elevated $\mathrm{CO}_{2}$ Conditions: A MetaAnalysis of Reports on 79 Crop and Wild Species. New Phytologist, 156, 9-26. http://dx.doi.org/10.1046/j.1469-8137.2002.00494.x

[18] Bunce, J.A. (2005) Seed Yield of Soybeans with Daytime or Continuous Elevation of Carbon Dioxide under Field Conditions. Photosynthetica, 43, 435-438. http://dx.doi.org/10.1007/s11099-005-0069-Z

[19] LaDeau, S.L. and Clark, J.S. (2006) Elevated $\mathrm{CO}_{2}$ and Tree Fecundity: The Role of Tree Size, Inter Annual Variability, and Population Heterogeneity. Global Change Biology, 12, 822-833. http://dx.doi.org/10.1111/j.1365-2486.2006.01137.x

[20] LaDeau, S.L. and Clark, J.S. (2006) Pollen Production by Pinus taeda Growing in Elevated Atmospheric $\mathrm{CO}_{2}$. Functional Ecology, 20, 541-547. http://dx.doi.org/10.1111/j.1365-2435.2006.01133.x

[21] Springer, C.J. and Ward, J.K. (2007) Flowering Time and Elevated Atmospheric $\mathrm{CO}_{2}$. New Phytologist, 176, $243-255$. http://dx.doi.org/10.1111/j.1469-8137.2007.02196.x

[22] Lotze-Campen, H. and Schellnhuber, H.J. (2009) Climate Impacts and Adaptation Options in Agriculture: What We Know and What We Don't Know. Journal für Verbraucherschutz und Lebensmittelsicherheit, 4, 145-150. http://dx.doi.org/10.1007/s00003-009-0473-6

[23] Kimball, B.A. (2011) Lessons from FACE: $\mathrm{CO}_{2}$ Effects and Interactions with Water, Nitrogen, and Temperature. In: Hillel, D. and Rosenzweig, C., Eds., Handbook of Climate Change and Agroecosystems: Impacts, Adaptation, and Mitigation, Imperial College Press, London, 87-107.

[24] Kimball, B.A. (1983) Carbon Dioxide and Agricultural Yield: An Assemblage and Analysis of 430 Prior Observations. Agronomy Journal, 75, 779-788. http://dx.doi.org/10.2134/agronj1983.00021962007500050014x

[25] Poorter, H., Berkel, Y.V., Baxter, R., Den Hertog, J., Dijkstra, P., Gifford, R.M., et al. (1997) The Effect of Elevated $\mathrm{CO}_{2}$ on the Chemical Composition and Construction Costs of Leaves of $27 \mathrm{C}_{3}$ Species. Plant, Cell and Environment, 20, 472-482. http://dx.doi.org/10.1046/j.1365-3040.1997.d01-84.x

[26] Ewert, F., Rodriguez, D., Jamieson, P., Semenov, M.A., Mitchell, R.A.C., Goudriaan, J., Porter, J.R., Kimball, B.A., Pinter Jr., P.J., Manderscheid, R., Weigel, H.J., Fangmeier, A., Fereres, E. and Villalobos, F. (2002) Effects of Elevated $\mathrm{CO}_{2}$ and Drought on Wheat: Testing Crop Simulation Models for Different Experimental and Climatic Conditions. Agriculture, Ecosystems and Environment, 93, 249-266. http://dx.doi.org/10.1016/S0167-8809(01)00352-8

[27] Cure, J.D. and Acock, B. (1986) Crop Responses to Carbon Dioxide Doubling: A Literature Survey. Agricultural and Forest Meteorology, 38, 127-145. http://dx.doi.org/10.1016/0168-1923(86)90054-7

[28] Amthor, J.S. (2001) Effects of Atmospheric $\mathrm{CO}_{2}$ Concentration on Wheat Yield: Review of Results from Experiments Using Various Approaches to Control $\mathrm{CO}_{2}$ Concentration. Field Crops Research, 73, 1-34.

http://dx.doi.org/10.1016/S0378-4290(01)00179-4

[29] Pickering, N.B., Allen Jr., F.L.H., Albrecht, S.L., Jones, P., Jones, J.W. and Baker, J.T. (1994) Environmental Plant Chambers: Controls and Measurements Using CR-10T Data Loggers. In: Watson, D.G., Zuzueta, F.S. and Harrison, T.V., Eds., Computers in Agriculture: Proceedings of the 5th International Conference, American Society of Agricultural Engineers, Orlando, 5-9 February 1994, 29-35.

[30] Allen Jr., L.H. and Boote, K.J. (2000) Crop Ecosystem Responses to Climate Change: Soybean. In: Reddy, K.R. and Hodges, H.F., Eds., Climate Change and Global Crop Productivity, CABI Publishing, Oxon, 133-160. http://dx.doi.org/10.1079/9780851994390.0133

[31] Reddy, K.R., Kakani, V.G., Zhao, D., Koti, S. and Gao, W. (2004) Interactive Effects of Ultraviolet-B Radiation and 
Temperature on Cotton Physiology, Growth, Development and Hyperspectral Reflectance. Photochemistry and Photobiology, 79, 416-427. http://dx.doi.org/10.1562/2003-11-19-RA.1

[32] Singh, G. and Shivakumar, B.G. (2010) The Role of Soybean in Agriculture. In: Singh, B., Ed., The Soybean: Botany, Production and Uses, CAB International, Oxfordshire, 24-47.

[33] Lisar, S.Y.S., Motafakkerazad, R., Hossain, M.M. and Rahman, I.M.M. (2012) Water Stress in Plants: Causes, Effects and Responses. In: Rahman, I.M.M. and Hasegawa, H., Eds., Water Stress, InTech, Croatia, 1-14.

[34] Gerten, D. and Rost, S. (2010) Development and Climate Change: Climate Change Impacts on Agricultural Water Stress and Impact Mitigation Potential. Potsdam Institute for Climate Impact Research (PIK), Potsdam, 8 p.

[35] Klepper, B. and Kaspar, T.C. (1994) Rhizotrons: Their Development and Use in Agricultural Research. Agronomy Journal, 86, 745-753. http://dx.doi.org/10.2134/agronj1994.00021962008600050002x

[36] Gardner, F.P., Pearce, R.B. and Mitchell, R.A.C. (1988) Growth and Development. In: Physiology of Crop Plants, The Iowa State University Press, Ames, 185-208.

[37] Walkley, A. and Black, I.A. (1934) An Examination of Degtjareff Methods for Determining Soil Organic Matter and Proposed Modification of the Chromic Acid Titration Method. Soil Science, 37, 29-38. http://dx.doi.org/10.1097/00010694-193401000-00003

[38] Baker, J.T., Allen Jr., L.H., Boote, K.J., Jones, P. and Jones, J.W. (1989) Response of Soybean to Air Temperature and Carbon Dioxide Concentration. Crop Science, 29, 98-105. http://dx.doi.org/10.2135/cropsci1989.0011183X002900010024x

[39] Allen Jr., L.H., Bisbal, E.C., Campbell, W.J. and Boote, K.J. (1990) Carbon Dioxide Effects on Soybean Developmental Stages and Expansive Growth. Soil and Crop Science Society of Florida Proceedings, 49, 124-131.

[40] Allen Jr., L.H., Bisbal, E.C., Boote, K.J. and Jones, P.H. (1991) Soybean Dry Matter Allocation under Subambient and Super Ambient Levels of Carbon Dioxide. Agronomy Journal, 83, 875-883. http://dx.doi.org/10.2134/agronj1991.00021962008300050020x

[41] Allen Jr., L.H., Vu, J.C.V., Valle, R.R., Boote, K.J. and Jones, P.H. (1988) Nonstructural Carbohydrates and Nitrogen of Soybean Grown under Carbon Dioxide Enrichment. Crop Science, 28, 84-94. http://dx.doi.org/10.2135/cropsci1988.0011183X002800010020x

[42] Ahmed, F.E., Hall, A.E. and Madore, M.A. (1993) Interactive Effects of High-Temperature and Elevated Carbon Dioxide Concentration on Cowpea [Vigna unguiculata (L.) Walp]. Plant, Cell and Environment, 16, 835-842. http://dx.doi.org/10.1111/j.1365-3040.1993.tb00505.x

[43] Prasad, P.V.V., Boote, K.J., Allen Jr., L.H. and Thomas, J.M.G. (2002) Effects of Elevated Temperature and Carbon Dioxide on Seed-Set and Yield of Kidney Bean (Phaseolus vulgaris L.). Global Change Biology, 8, 710-721. http://dx.doi.org/10.1046/j.1365-2486.2002.00508.x

[44] Rogers, H.H., Cure, J.D., Thomas, J.F. and Smith, J.M. (1984) Influence of Elevated $\mathrm{CO}_{2}$ on Growth of Soybean Plants. Crop Science, 24, 361-366. http://dx.doi.org/10.2135/cropsci1984.0011183X002400020036x

[45] Bhattacharya, S., Bhattacharya, N.C., Biswas, P.K. and Strain, B.R. (1985) Response of Cow Pea (Vigna unguiculata L.) to $\mathrm{CO}_{2}$ Enrichment Environment on Growth, Dry Matter Production and Yield Components at Different Stages of Vegetative and Reproductive Growth. Journal of Agricultural Science (Cambridge), 105, 527-534. http://dx.doi.org/10.1017/S0021859600059414

[46] Ellis, R.H., Craufurd, P.Q., Summerfield, R.J. and Roberts, E.H. (1995) Linear Relations between Carbon Dioxide Concentration and Rate of Development towards Flowering in Sorghum, Cowpea and Soybean. Annals of Botany, 75, 193-198. http://dx.doi.org/10.1006/anbo.1995.1012

[47] Prasad, P.V.V., Allen Jr., L.H. and Boote, K.J. (2005) Crop Responses to Elevated Carbon Dioxide and Interaction with Temperature: Grain Legumes. Journal of Crop Improvement, 13, 113-155.

[48] Valle, R., Mishoe, J.W., Jones, J.W. and Allen Jr., L.H. (1985) Transpiration Rate and Water-Use Efficiency of Soybean Leaves Adapted to Different $\mathrm{CO}_{2}$ Environments. Crop Science, 25, 477-482. http://dx.doi.org/10.2135/cropsci1985.0011183X002500030011x

[49] Castro, J.C., Dohleman, F.G., Bernacchi, C.J. and Long, S.P. (2009) Elevated $\mathrm{CO}_{2}$ Significantly Delays Reproductive Development of Soybean under Free-Air Concentration Enrichment (FACE). Journal of Experimental Botany, 60, 2945-2951. http://dx.doi.org/10.1093/jxb/erp170

[50] Wu, D.X., Wang, G.X., Bai, Y.F. and Liao, J.X. (2004) Effects of Elevated $\mathrm{CO}_{2}$ Concentration on Growth, Water Use, Yield and Grain Quality of Wheat under Two Soil Water Levels. Agriculture, Ecosystems and Environment, 104, 493507. http://dx.doi.org/10.1016/j.agee.2004.01.018

[51] Baker, J.T. and Allen Jr., L.H. (1993) Contrasting Crop Species Responses to $\mathrm{CO}_{2}$ and Temperature: Rice, Soybean, and Citrus. Vegetatio, 104-105, 239-260. http://dx.doi.org/10.1007/BF00048156 
[52] Sasek, T.W. and Strain, B.R. (1991) Effects of $\mathrm{CO}_{2}$ Enrichment on the Growth and Morphology of a Native and Introduced Honey Suckle Vine. American Journal of Botany, 78, 69-75. http://dx.doi.org/10.2307/2445229

[53] Pal, M., Karthikeyapandian, V., Jain, V., Srivastava, A.C., Raj, A. and Sengupta, U.K. (2004) Biomass Production and Nutritional Levels of Berseem (Trifolium alexandrium) Grown under Elevated $\mathrm{CO}_{2}$. Agriculture, Ecosystems and Environment, 101, 31-38. http://dx.doi.org/10.1016/S0167-8809(03)00202-0

[54] Cure, J.D., Rufty, T.W. and Israel, D.W. (1988) Phosphorus Stress Effects on Growth and Seed Yield Responses of Non-Nodulated Soybean to Elevated Carbon Dioxide. Agronomy Journal, 80, 897-902. http://dx.doi.org/10.2134/agronj1988.00021962008000060012x

[55] Thomas, J.F. and Harvey, C.N. (1983) Leaf Anatomy of Four Species Grown under Continuous $\mathrm{CO}_{2}$ Enrichment. Botanical Gazette, 144, 303-309. http://dx.doi.org/10.1086/337377

[56] Cure, J.F., Rufty, T.W. and Israel, D.W. (1987) Assimilate Utilization in the Leaf Canopy and Whole Plant Growth of Soybean during Acclimation to Elevated $\mathrm{CO}_{2}$. Botanical Gazette, 148, 67-72. http://dx.doi.org/10.1086/337628

[57] Campbell, W.J., Allen Jr., L.H. and Bowes, G. (1988) Effects of $\mathrm{CO}_{2}$ Concentration on Rubisco Activity, Amount, and Photosynthesis in Soybean Leaves. Plant Physiology, 88, 1310-1316. http://dx.doi.org/10.1104/pp.88.4.1310

[58] Leadley, P.W. and Reynolds, J.F. (1988) Effects of Elevated Carbon Dioxide on Estimation of Leaf Area and Leaf Dry Weights of Soybean. American Journal of Botany, 75, 1771-1774. http://dx.doi.org/10.2307/2444692

[59] Vu, J.C.V., Gesch, R.W., Pennanen, A.H., Allen Jr., L.H., Boote, K.J. and Bowes, G. (2001) Soybean Photosynthesis, Rubisco and Carbohydrate Enzymes Function at Supra-Optimal Temperatures in Elevated $\mathrm{CO}_{2}$. Journal of Plant Physiology, 158, 295-307. http://dx.doi.org/10.1078/0176-1617-00290

[60] Müller, J. (1993) Stoffbildung, $\mathrm{CO}_{2}$-Gaswechsel, Kohlenhydrat- und Stickstoffgehalt von Winterweizen bei erhöhter $\mathrm{CO}_{2}$-Konzentration und Trocken-streß. Journal of Agronomy and Crop Science, 171, 217-235. [Dry Matter Production, $\left[\mathrm{CO}_{2}\right]$ Exchange, Carbohydrate and Nitrogen Content of Winter Wheat at Elevated $\left[\mathrm{CO}_{2}\right]$ Concentration and Drought Stress. Journal of Agronomy and Crop Science, 171, 217-235.] http://dx.doi.org/10.1111/j.1439-037X.1993.tb00134.X

[61] Christ, R.A. and Körner, C. (1995) Responses of Shoot and Root Gas Exchange, Leaf Blade Expansion and Biomass Production to Pulses of Elevated $\mathrm{CO}_{2}$ in Hydroponic Wheat. Journal of Experimental Botany, 46, 1661-1667. http://dx.doi.org/10.1093/jxb/46.11.1661

[62] Sæbø, A. and Mortensen, L.M. (1996) Growth, Morphology and Yield of Wheat, Barley and Oats Grown at Elevated Atmospheric $\mathrm{CO}_{2}$ Concentration in a Cool, Maritime Climate. Agriculture, Ecosystems and Environment, 57, 9-15. http://dx.doi.org/10.1016/0167-8809(95)01009-2

[63] Mulholland, B.J., Craigon, J., Black, C.R., Colls, J.J., Atherton, J. and Landon, G. (1998) Growth, Light Interception and Yield Responses of Spring Wheat (Triticum aestivum L.) Grown under Elevated $\mathrm{CO}_{2}$ and $\mathrm{O}_{3}$ in Open-Top Chambers. Global Change Biology, 4, 121-130. http://dx.doi.org/10.1046/j.1365-2486.1998.00112.x

[64] Pritchard, S.G., Rogers, H.H., Prior, S.A. and Peterson, C.M. (1999) Elevated $\mathrm{CO}_{2}$ and Plant Structure: A Review. Global Change Biology, 5, 807-837. http://dx.doi.org/10.1046/j.1365-2486.1999.00268.x

[65] Allen Jr., L.H., Boote, K.J., Jones, J.W., Jones, P.H., Valle, R.R., Acock, B., Rogers, H. and Dahlman, R.C. (1987) Responses of Vegetation to Rising $\mathrm{CO}_{2}$ : Photosynthesis, Biomass and Seed Yield of Soybean. Global Biochemistry Cycles, 1, 1-14. http://dx.doi.org/10.1029/GB001i001p00001

[66] Baker, J.T. and Allen Jr., L.H. (1994) Assessment of the Impact of Rising Carbon Dioxide and Other Potential Climate Changes on Vegetation. Environmental Pollution, 83, 223-235. http://dx.doi.org/10.1016/0269-7491(94)90037-X

[67] Pan, D. (1996) Soybean Responses to Elevated Temperature and Doubled $\mathrm{CO}_{2}$. Ph.D. Dissertation, University of Florida, Gainesville, Dissertation Abstracts International 57, no. 10B, (1996): 5987. Accession No. AAG709292.

[68] Clifford, S.C., Stronach, I.M., Mohamed, A.D., Azamali, S.N. and Crout, N.M.J. (1993) The Effects of Elevated Atmospheric Carbon Dioxide and Water Stress on Light Interception, Dry Matter Production and Yield in Stands of Groundnut (Arachis hypogaea L.). Journal of Experimental Botany, 44, 1763-1770. http://dx.doi.org/10.1093/jxb/44.12.1763

[69] Clifford, S.C., Stronach, I.M., Black, C.R., Singleton-Jones, P.R., Azam-Ali, S.N. and Crout, N.M.J. (2000) Effects of Elevated $\mathrm{CO}_{2}$, Drought and Temperature on the Water Relations and Gas Exchange of Groundnut (Arachis hypogaea) Stands Grown in Controlled Environment Glasshouses. Physiologia Plantarum, 110, 78-88. http://dx.doi.org/10.1034/j.1399-3054.2000.110111.x

[70] Overdieck, D., Reid, C. and Strain, B.R. (1988) The Effects of Preindustrial and Future $\mathrm{CO}_{2}$ Concentrations on Growth, Dry Matter Production and the C/N Relationship in Plants at Low Nutrient Supply: Vigna unguiculata (Cowpea), Abelmoschus esculentus (Orka) and Raphinus sativus (Radish). Angewandte Botanik, 62, 119-134.

[71] Sharma, A. and Sengupta, U.K. (1990) Carbon Dioxide Enrichment Effect on Photosynthesis and Related Enzymes in Vigna radiate Wilczek. Indian Journal of Plant Physiology, 33, 340-346. 
[72] Gifford, R.M. (1979) Growth and Yield of $\mathrm{CO}_{2}$ Enriched Wheat under Water-Limited Conditions. Australian Journal of Plant Physiology, 6, 367-378. http://dx.doi.org/10.1071/PP9790367

[73] Idso, K.E. and Idso, S.B. (1994) Plant Responses to Atmospheric $\mathrm{CO}_{2}$ Enrichment in the Face of Environmental Constraint: A Review of the Past 10 Year's Research. Agricultural and Forest Meteorology, 69, 153-203.

[74] Kang, S.Z., Zhang, F.C., Hu, X.T. and Zhang, J.H. (2002) Benefits of $\mathrm{CO}_{2}$ Enrichment on Crop Plants Are Modified by Soil Water. Plant and Soil, 238, 69-77. http://dx.doi.org/10.1023/A:1014244413067

[75] Kramer, P.J. (1981) Carbon Dioxide Concentration, Photosynthesis, and Dry Matter Production. Bioscience, 31, 29-33. http://dx.doi.org/10.2307/1308175

[76] Poorter, H. (1993) Interspecific Variation in the Growth Response of Plants to an Elevated Ambient $\mathrm{CO}_{2}$ Concentration. Vegetatio, 104-105, 77-97. http://dx.doi.org/10.1007/BF00048146

[77] Hunt, R., Hand, D.W., Hannah, M.A. and Neal, A.M. (1995) Temporal and Nutritional Influences on the Response to Elevated $\mathrm{CO}_{2}$ in Selected British Grasses. Annals of Botany, 75, 207-216. http://dx.doi.org/10.1006/anbo.1995.1014

[78] Thompson, G.B. and Woodward, F.I. (1994) Some Influences of $\mathrm{CO}_{2}$ Enrichment, Nitrogen Nutrition and Competition on Grain Yield and Quality in Spring Wheat and Barley. Journal of Experimental Botany, 45, 937-942.

[79] Bunce, J.A. (1998) The Temperature Dependence of the Stimulation of Photosynthesis by Elevated Carbon Dioxide in Wheat and Barley. Journal of Experimental Botany, 49, 1555-1561. http://dx.doi.org/10.1093/jxb/49.326.1555

[80] Poorter, H. (1998) Do Slow-Growing Species and Nutrient-Stressed Plants Respond Relatively Strongly to Elevated $\mathrm{CO}_{2}$ ? Global Change Biology, 4, 693-697. http://dx.doi.org/10.1046/j.1365-2486.1998.00177.x

[81] Wu, D.X. and Wang, G.X. (2000) Interaction of $\mathrm{CO}_{2}$ Enrichment and Drought on Growth, Water Use, and Yield of Broad Bean (Vicia faba). Environmental and Experimental Botany, 43, 131-139. http://dx.doi.org/10.1016/S0098-8472(99)00053-2

[82] Hocking, P.J. and Meyer, C.P. (1991) $\mathrm{CO}_{2}$ Enrichment Decreases Critical Nitrate and Nitrogen Concentration in Wheat. Journal of Plant Nutrition, 14, 571-584. http://dx.doi.org/10.1080/01904169109364225

[83] Coleman, J.S., Connaughay, K.D.M. and Bazzaz, F.A. (1993) Elevated $\mathrm{CO}_{2}$ and Plant Nitrogen Use: Is Reduced Tissue Nitrogen Concentration Size-Dependent? Oecologia, 93, 195-200. http://dx.doi.org/10.1007/BF00317671

[84] Conroy, J. and Hocking, P. (1993) Nitrogen Nutrition of $\mathrm{C}_{3}$ Plants at Elevated Atmospheric $\mathrm{CO}_{2}$ Concentrations. Physiologia Plantarum, 89, 570-576. http://dx.doi.org/10.1111/j.1399-3054.1993.tb05215.x

[85] Cotrufo, M.F., Ineson, P. and Scott, A. (1998) Elevated $\mathrm{CO}_{2}$ Reduces the Nitrogen Concentration of Plant Tissues. Global Change Biology, 4, 43-54. http://dx.doi.org/10.1046/j.1365-2486.1998.00101.x

[86] Taub, D.R. and Wang, X.Z. (2008) Why Are Nitrogen Concentrations in Plant Tissues Lower under Elevated $\mathrm{CO}_{2}$ ? A Critical Examination of the Hypotheses. Journal of Integrative Plant Biology, 50, 1365-1374. http://dx.doi.org/10.1111/j.1744-7909.2008.00754.x

[87] Bloom, A.J., Burger, M., Asensio, J.S.R. and Cousins, A.B. (2010) Carbon Dioxide Enrichment Inhibits Nitrate Assimilation in Wheat and Arabidopsis. Science, 328, 899-903. http://dx.doi.org/10.1126/science. 1186440

[88] Ainsworth, E.A. and Long, S.P. (2005) What Have We Learned from 15 Years of Free-Air $\mathrm{CO}_{2}$ Enrichment (FACE)? A Meta-Analytic Review of the Responses of Photosynthesis, Canopy Properties and Plant Production to Rising $\mathrm{CO}_{2}$. New Phytologist, 165, 351-372. http://dx.doi.org/10.1111/j.1469-8137.2004.01224.x

[89] Curtis, P.S., Snow, A.A. and Miller, A.S. (1994) Genotype-Specific Effects of Elevated $\mathrm{CO}_{2}$ on Fecundity in Wild Radish (Raphanus raphanistum). Oecologia, 97, 100-105. http://dx.doi.org/10.1007/BF00317913

[90] Curtis, P.S., Klus, D.J., Kalisz, S. and Tonsor, S.J. (1996) Intraspecific Variation in $\mathrm{CO}_{2}$ Responses in Raphanus raphinistum and Plantago lanceolata: Assessing the Potential for Evolutionary Change with Rising Atmospheric Change. In: Korner, C. and Bazzaz, F.A., Eds., Carbon Dioxide, Populations and Communities, Academic Press, New York, $13-22$.

[91] Johnson, S.L. and Lincoln, D.E. (2000) Allocation Responses to $\mathrm{CO}_{2}$ Enrichment and Defoliation by a Native Annual Plant Heterotheca subaxillaris. Global Change Biology, 6, 767-778. http://dx.doi.org/10.1046/j.1365-2486.2000.00355.x

[92] Edwards, G.R., Clark, H. and Newton, P. (2001) The Effects of Elevated $\mathrm{CO}_{2}$ on Seed Production and Seedling Recruitment in a Sheep Grazed Pasture. Oecologia, 127, 383-394. http://dx.doi.org/10.1007/s004420000602

[93] Deng, X. and Woodward, F.I. (1998) The Growth and Yield Responses of Fragaria ananassa to Elevated $\mathrm{CO}_{2}$ and $\mathrm{N}$ Supply. Annals of Botany, 81, 67-71. http://dx.doi.org/10.1006/anbo.1997.0535

[94] Sung, F.J.M. and Chen, J.J. (1991) Gas Exchange Rate and Yield Response of Strawberry to Carbon Dioxide Enrichment. Scientia Horticulturae, 48, 241-251. http://dx.doi.org/10.1016/0304-4238(91)90132-I

[95] Downton, W.J.S., Grant, W.J.R. and Loveys, B.R. (1987) Carbon Dioxide Enrichment Increases Yield of Valencia 
Orange. Australian Journal of Plant Physiology, 14, 493-501. http://dx.doi.org/10.1071/PP9870493

[96] Schortemeyer, M., Atkin, O.K., McFarlane, N. and Evans, J.R. (2002) $\mathrm{N}_{2}$ Fixation by Acacia Species Increases under Elevated Atmospheric $\mathrm{CO}_{2}$. Plant, Cell \& Environment, 25, 567-579. http://dx.doi.org/10.1046/j.1365-3040.2002.00831.x

[97] Haase, S., Neumann, G., Kania, A., Kuzyakov, Y., Romheld, V. and Kandeler, E. (2007) Elevation of Atmospheric $\mathrm{CO}_{2}$ and N-Nutritional Status Modify Nodulation, Nodule-Carbon Supply, and Root Exudation of Phaseolus vulgaris L. Soil Biology and Biochemistry, 39, 2208-2221. http://dx.doi.org/10.1016/j.soilbio.2007.03.014

[98] Prevost, D., Bertrand, A., Juge, C. and Chalifour, F.P. (2010) Elevated $\mathrm{CO}_{2}$ Induces Differences in Nodulation of Soybean Depending on Bradyrhizobial Strain and Method of Inoculation. Plant and Soil, 331, 115-127. http://dx.doi.org/10.1007/s11104-009-0238-0

[99] Reddy, V.R., Acock, B. and Acock, M.C. (1989) Seasonal Carbon and Nitrogen Accumulation in Relation to Net Carbon Dioxide Exchange in a Carbon Dioxide Enriched Soybean Canopy. Agronomy Journal, 81, 78-83. http://dx.doi.org/10.2134/agronj1989.00021962008100010014x

[100] Reardon, J.C., Lambert, J.R. and Acock, B. (1990) The Influence of Carbon Dioxide Enrichment on the Seasonal Patterns of Nitrogen Fixation in Soybean. In: Responses of Vegetation to Carbon Dioxide, Series 016, US Department of Energy and USDAARS, Washington DC, 94.

[101] Rogers, A., Gibon, Y., Stitt, M., Morgan, P.B., Bernacchi, C.J., Ort, D.R. and Long, S.P. (2006) Increased C Availability at Elevated Carbon Dioxide Concentration Improves N Assimilation in a Legume. Plant, Cell \& Environment, 29, 1651-1658. http://dx.doi.org/10.1111/j.1365-3040.2006.01549.x

[102] Rogers, A., Ainsworth, E.A. and Leakey, A.D.B. (2009) Will Elevated Carbon Dioxide Concentration Amplify the Benefits of Nitrogen Fixation in Legumes? Plant Physiology, 151, 1009-1016. http://dx.doi.org/10.1104/pp.109.144113

[103] Gray, S.B., Strellner, R.S., Puthuval, K.K., Ng, C., Shulman, R.E., Siebers, M.H., Rogers, A. and Leakey, A.D.B. (2013) Minirhizotron Imaging Reveals that Nodulation of Field-Grown Soybean Is Enhanced by Free-Air $\mathrm{CO}_{2}$ Enrichment Only When Combined with Drought Stress. Functional Plant Biology, 40, 137-147. http://dx.doi.org/10.1071/FP12044

[104]Zahran, H.H. (1999) Rhizobium-Legume Symbiosis and Nitrogen Fixation under Severe Conditions and in an Arid Climate. Microbiology and Molecular Biology Reviews, 63, 968-989.

[105] Antolín, M.C., Muro, I. and Sánchez-Díaz, M. (2010) Application of Sewage Sludge Improves Growth, Photosynthesis and Antioxidant Activities of Nodulated Alfalfa Plants under Drought Conditions. Environmental and Experimental Botany, 68, 75-82. http://dx.doi.org/10.1016/j.envexpbot.2009.11.001

[106] Kimball, B.A. (1985) Adaptation of Vegetation and Management Practices to a Higher Carbon Dioxide World. In: Strain, B.R. and Cure, J.D., Eds., Direct Effects of Increasing Carbon Dioxide on Vegetation, U.S. Department of Energy, DOE/ER-0238, Washington DC, 185-204.

[107] Catovsky, S. and Bazzaz, F.A. (1999) Elevated $\mathrm{CO}_{2}$ Influences the Responses of Two Birch Species to Soil Moisture: Implications for Forest Community Structure. Global Change Biology, 5, 507-518. http://dx.doi.org/10.1046/j.1365-2486.1999.00247.x

[108] Ward, J.K., Tissue, D.T., Thomas, R.B. and Strain, B.R. (1999) Comparative Responses of Model C3 and C4 Plants to Drought in Low and Elevated $\mathrm{CO}_{2}$. Global Change Biology, 5, 857-867. http://dx.doi.org/10.1046/j.1365-2486.1999.00270.x

[109] Cardoso-Vilhena, J. and Barnes, J. (2001) Does Nitrogen Supply Affect the Response of Wheat (Triticum aestivum cv. Hanno) to the Combination of Elevated $\mathrm{CO}_{2}$ and $\mathrm{O}_{3}$ ? Journal of Experimental Botany, 52, 1901-1911. http://dx.doi.org/10.1093/jexbot/52.362.1901 